\title{
The Uneasy Case for Enforcing Competition Law Provisions Related with Excessive and Unfair Prices in Developing Countries*
}

\author{
AndRÉs Palacios-Lleras ${ }^{* *}$
}

\begin{abstract}
This article argues in favor of having competition law authorities of developing countries enforce provisions that, like article 102.a of the Treaty on the Functioning of the European Union (TFEU), forbid charging excessive and unfairly high prices. In order to do so, it analyzes the relevant European Union (EU) case law and the considerations it has brought forth, as well as studies regarding competition law enforcement in developing countries, in order to determine the relevant factors that may contribute to the successful enforcement in these jurisdictions. It also takes into consideration the difficulties that have resulted in the enforcement of the aforementioned provision, how they may take place in developing countries, and what can be done to resolve them. It concludes that such a successful enforcement is possible, if the relevant authorities, after assessing their institutional background, find their own voice for doing so. In turn, such enforcement not necessarily quarrels with efficiency considerations, but rather complements them with considerations stemming from other non-economic goals.
\end{abstract}

Key words author: Article 102.a TFEU, Competition Law and Development, Developing Countries, Excessive Prices.

Key word plus: Antitrust Law, Monopolization.

JEL Classification: K21, L41.

* Review article on Antitrust Law, based on the author's teaching experience, on going research and his professional practice in Economic Law.

** Master of Laws (LL.M.) Harvard Law School and lawyer from Universidad de Los Andes. Professor of economic law and law and economics at Universidad de Los Andes, Pontificia Universidad Javeriana, and Universidad Externado de Colombia. Associate lawyer Estudios Palacios Lleras S.A.S. Contact: apalacios@palacioslleras.com 


\section{¿DEben los países en desarrollo implementar nORMAS DE COMPETENCIA RELACIONADAS CON LA FIJACIÓN DE PRECIOS EXCESIVOS E INJUSTOS?}

\section{RESUMEN}

Este artículo sugiere que, a pesar de los temores, las autoridades de competencia de países en desarrollo deberían aplicar consistentemente aquellos artículos de sus legislaciones que, al igual que el 102.a del Tratado de Funcionamiento de la Unión Europea (TFUE), establecen una prohibición al cobro de precios inequitativamente altos como manifestaciones del abuso de la posición dominante. Para ello, este texto analiza los casos decididos en la Unión Europea (UE) y las reflexiones que han suscitado, junto con estudios sobre el derecho de la competencia en países en desarrollo, para así determinar los factores relevantes que pueden contribuir a la aplicación exitosa de dichos artículos en estos países. Así mismo, se describen los problemas que han surgido al aplicar el mencionado artículo, cómo pueden manifestarse en países en desarrollo, y qué se puede hacer para aminorar sus consecuencias. A manera de conclusión, consideramos que la aplicación exitosa de este tipo de artículos es posible, pero ello depende de que las autoridades de competencia sean conscientes de su entorno institucional, y desarrollen sus propias formas de llevar a cabo esta labor. A su vez, tal aplicación puede ser consistente con nociones de eficiencia económica y con los otros propósitos y principios que orientan el derecho de la competencia en los países en desarrollo.

Palabras clave autor: artículo 102.a TFUE, derecho de la competencia y desarrollo, países en desarrollo, precios excesivos.

Palabras clave descriptor: derecho de la competencia, monopolio.

Clasificación JEL: K21, L41. 


\section{LES PAYS EN DÉVELOPPEMENT DOIVENT-ILS METTRE EN OEUVRE DES NORMES DE CONCURRENCE EN CAS DE FIXATION DE PRIX EXCESSIFS ET INJUSTES?}

RÉSUMÉ

Cet article suggère que, malgré les craintes, les autorités compétentes de pays en développement devraient appliquer de manière consistante ces articles de leurs législations qui, tout comme le 102.a du Traité de Fonctionnement de l'Union Européenne (TFUE), établissent une interdiction d'encaisser des prix élevés et nonéquitatifs comme manifestations de l'abus de position dominante. À cet effet, ce texte analyse les cas décidés dans l'Union Européenne (UE) et les réflexions qu'ils ont suscitées, avec des études sur le droit de la concurrence dans des pays en développement, pour déterminer ainsi les facteurs significatifs qui peuvent contribuer à l'application réussie de ces articles dans ces pays. De même, les problèmes qui sont apparus dans l'application de l'article mentionné sont décris; comme ils peuvent apparaître dans des pays en développement, et ce qu'il peut être fait pour amoindrir leurs conséquences. À manière de conclusion, nous considérons que l'application réussie de ce type d'articles est possible, mais cela dépend du fait que les autorités de la concurrence soient conscientes de leur environnement institutionnel, et qu'elles développent leur propre façon de mener à bien cette tâche. À son tour, une telle application peut être consistante avec des notions d'efficience économique et avec les autres buts et principes

Mots clés auteur: article 102.a TFUE, droit de la concurrence et du développement, pays en voie de développement, prix excessifs.

Mots clés descripteur: droit de la concurrence, monopole.

Classification JEL: K21, L41. 
Summary: Introduction. 1. A Brief Review of the Enforcement of Article 102.a TFEU. 2. Two Perspectives on Competition Law in Developing Countries and their Usefulness for Enforcing Excessive and Unfair Price Provisions. 3. Enforcing Provisions Against Excessive and Unfair Prices: The Yacimientos Petroliferos Fiscales and Mittal Steel cases. Conclusion: The Uneasy Case for Enforcing Competition Law Provisions Related with Excessive and Unfair Prices in Developing Countries. Bibliography.

\section{INTRODUCTION}

Recent literature on comparative competition law places a strong emphasis on the conditions for success of a set of competition law institutions, including cultural, legal and political factors. It is commonly accepted that these are "preconditions" that are required for competition law institutions to take hold on the jurisdictions to which they are transplanted and develop successfully ${ }^{1}$. However, a topic seldom addressed by the comparative law literature is the transplant of institutions which are only partially implemented in their original jurisdiction, and what this implies for its possibilities of development in the receiving jurisdictions. Such is the case of article 102.a of the Treaty on the Functioning of the European Union (TFEU), which considers charging unfair prices an instance of abuse of dominance, and therefore, illegal ${ }^{2}$. This particular provision has been used in cases regarding exclusionary behavior, in which prices are considered too low, as in cases related with exploitative behavior, in which prices are considered too high. It is the latter, and not the former, which is the concern of the following pages.

Both the text and the idea behind article 102.a TFEU have been transplanted to several jurisdictions, in spite that it has been enforced rather sparsely by the relevant authorities, and presents formidable obstacles for a proper enforcement under contemporary competition law theory. Therefore, competition authorities in developing countries are aware of present day developments in this area of law should wonder to what extent their competition law regimes includes rules which, in their original context, were condemned to an illustrious but short life.

1 W. Spencer Waller, Neo-Realism and the International Harmonization of Law: Lessons from Antitrust, 42 U. of Kansas L. Rev., 557 (1994), available at SSRN http://ssrn.com/abstract=1062381. William E. Kovacic, Institutional Foundations for Economic Legal Reform in Transition Economies: The Case of Competition Policy and Antitrust Enforcement, 77 Chi.-Kent L. Rev., 265 (2001-2002). David J. Gerber, Competition Law, in Oxford Handbook of Comparative Law, available at SSRN http://ssrn.com/abstract=871710. See also Michal S. Gal, The Ecology of Antitrust: Preconditions for Competition Law Enforcement in Developing Countries, in Competition, Competitiveness and Development, pp. 20-38 (2004), available at SSRN http://ssrn.com/abstract=665181. The work of Michal Gal and Eleanor Fox, reviewed in this paper below, has been very important for the current development of this field (see infra).

2 Perhaps a notable exception is Michal S. Gal, The 'Cut and Paste' of Article 82 of the EC Treaty in Israel: Conditions for a Successful Transplant, NYU Law and Economics Research Paper 08-03, available at SSRN http://ssrn.com/abstract=1082035. 
In this article, I argue that developing countries who already have provisions similar to article 102.a TFEU should thrive for its enforcement by developing their own legal rhetoric for it, in spite of the difficulties that enforcement attempts have had in their original jurisdiction. The adequate enforcement of this provision can contribute to the development of competitive markets and, just as important, can contribute to the legitimization of markets in the eyes of the general public. It does so by suggesting that there should be a degree of fairness in market transactions, a notion people have and upon which the asses the desirability of market - oriented outcomes. Moreover, it can become a second-best option for controlling abusive behavior by market participants, including exploitative behavior, which can be inefficient as well as unfair. This is especially valuable for developing countries in which state privatizations have contributed to the creation of local, privately-owned monopolies, and in which ex-ante regulation has been unsuccessful for curbing abuses of economic power. Finally, both the legitimizing effect and the second-best argument my fall squarely within the legal culture of particular developing countries, and more specifically, of their constitutional foundations. These three arguments suggest the extent to which developing countries could benefit importantly from developing their own understanding of how this sort of provisions should be enforced.

Against this milieu of positive aspirations, it is important to remain aware of the formidable obstacles that the enforcement of article 102.a TFEU faces in its own jurisdiction, and that has prevented the European Commission (EC) from engaging in a more decided enforcement. As the history of the enforcement of this provision suggests, these obstacles amount to what appears to be an insurmountable difficulty for providing a rational, internally coherent and objective way of determining what constitutes an unfair, exploitative price. This is an issue that the competition authorities of developing countries should not take lightly, for it determines the extent to which their decisions can be conducive to the aforementioned goals, or may become obstacles to the goals they pursue.

This article is divided as follows: in section 1, a brief review of the decisions taken by the Directorate General of Competition within the European Commission (DGCOMP) and the European Court of Justice (ECJ) will be presented, in order to highlight the difficulties related to the enforcement of article 102.a TFEU. Based upon the relevant case law, this section also presents a series of scholarly views about how to address the problems raised by the enforcement of this provision. In section 2, I present a brief overview of two different perspectives related to how should competition law enforcement proceed in developing countries, and flesh out their significance for determining whether these authorities should enforce provisions similar or related to article 102.a TFEU. Also, I argue that developing countries exhibit particular conditions, related with past State interventions, the privatization of State monopolies and others that justify the enforcement of the aforementioned provisions decisively, but not 
hastily. Then, on section 3, I briefly comment on two cases related with the enforcement of the aforementioned provisions, the Yacimientos Petroliferos Fiscales case in Argentina, and the Mittal Steel case in South Africa. As these two cases suggest, the conditions of developing countries which justify the enforcement of provisions against excessive and unfair prices are common, and need to be addressed. Finally, this article concludes by presenting some reflections of the arguments presented in the previous sections.

\section{A Brief Review of the Enforcement of Article 102.A TFEU}

\subsection{The Case Law of Excessive Pricing}

Article 102.a TFEU states the following:

Any abuse by one or more undertakings of a dominant position within the common maket or in a substantial part of it shall be prohibited as incompatible with the common market insofar as it may affect trade between Member States.

Such abuse may, in particular, consist in:

a) directly or indirectly imposing unfair purchase or selling prices or other unfair trade conditions;

There is a considerable amount of literature regarding the ideas that inspired article 102 TFEU, as well as its historical developments. David Gerber's account of the history of this article emphasizes the importance of ordoliberal ideas in the design and draft of articles 81 and 82 of the Treaty establishing the European Economic Community (EEC) Treaty of 1957, later renumbered as articles 101 and 102 TFEU. According to this account, the drafters of this article were well familiarized with ordoliberal ideas related to the control of private economic power as a way of preventing abuses by market participants. In particular, article 102 TFEU reflects a concern for preserving the economic freedom of some market participants, like consumers, from the eventual abuses that other participants, like monopolists, might incur. Moreover, the development of a common market was necessary for the economic integration of Europe, which in turn was considered instrumental for the political and social unification of the continent, as stated in the principles of the treaty itself. Therefore, it is suggests concern for particular abuses that threaten with preventing a deeper integration between the different member States. From this perspective, ordoliberal

3 Article 102.a TFEU, available at: http://eur-lex.europa.eu/LexUriServ/LexUriServ.do?uri=OJ:C:2008:115:00 47:0199 in PDF 
political and economic though provided the blueprint for the emergence and early development of European competition law ${ }^{4}$.

In spite of the ideas that inspired this provision, the application of its first literal (102.a TFEU) has been sparse, problematic and has produced important debates regarding about the proper role of competition law and its enforcers vis a vis markets and their participants. Much of this discussion has taken in light of the recent attempts to modernize the application of EU competition law from a "more economic approach", which in turn reflects the problems related to its application in particular cases. As it turns out, the experience related with this application and appreciated through the case law shows the extent to which ordoliberal ideals face important obstacles for providing an adequate basis for deciding cases.

The first enforcement attempt by the EC, the General Motors decision, was unsuccessful on the appeal due to lack of evidentiary support, precisely because of the nature of the allegations presented related with what constitutes an excessive price as a manifestation of an abuse of dominance ${ }^{5}$. The case is really about parallel imports; allegedly, General Motors (GM) charged excessive prices for certificates that allowed third parties to import their branded cars into Belgium from other Member States. Thus, the EC alleged that GM charged excessively high prices. As the EC stated:

[A]n excessive amount on the import of five motor vehicles manufactured in another Member State for the inspection for conformity with the specifications contained in the approval certificate prescribed by the Belgian Authorities (...) which it must carry out as the sole authorized agent of the manufacturer in Belgium ${ }^{6}$.

On the appeal, GM argued that allegedly excessive prices took place on a short period of time, resulted from complying with a duty imposed by the Belgium authorities and ended well before the EC issued the appealed decision. The ECJ accepted these arguments, reversed the decision, and went further as to manifest that prices which had little relation with the economic value of the services and impede parallel imports could constitute an abuse under article 102.a TFEU (formerly article 82 EEC). Paragraph 12 of the decision states this in the following terms:

Such an abuse might lie, inter alia, in the imposition of a price which is excessive in relation to the economic value of the services provided, and which has the effect of curbing parallel imports by neutralizing the possibly more favourable level of prices

4 David J. Gerber, Law and Competition in Twentieth Century Europe: Protecting Prometheus. Oxford University Press (1998). For a refreshing perspective, see Pinar Akman, Searching for the Long-Lost Soul of Article 82EC, available at https://www.uea.ac.uk/polopoly_fs/1.104585!ccp07-5.pdf.

5 Case 26/75, General Motors Continental NV v. Commission ECR 1367 (1975).

6 General Motors, op. cit., par. 1. 
applying in other sales areas in the Community, or by leading to unfair trade in the sense of Article 82(a) ${ }^{7}$.

In United Brands, the ECJ faced an appeal presented by United Brads Company (UBC), a mayor importer of Latin American bananas to different countries in Europe ${ }^{8}$. The EC alleged that the price of this fruit charged in Germany was much higher when compared to the price charged in Ireland; if UBC could sell its products in Ireland and still make a profit, this suggested that the higher price charged in Germany constituted an abuse. UBC challenged the decision, arguing that it did not have a dominant position and challenged the alleged basis on which the several abuse charges were made. In turn, the ECJ upheld the EC's analysis regarding the establishment of a dominant position, the presence of restrictive conditions, the occurrence of abuse based on refusal to supply, and the occurrence of abuse by discriminatory pricing; however, it strongly rejected the Commission's charges of exploitative pricing abuse, considering it improperly reasoned and elaborated. The ECJ stated:

In this case charging a price which is excessive because it has no reasonable relation to the economic value of the product supplied would be such an abuse. (...) This excess could, inter alia, be determined objectively if it were possible for it to be calculated by making a comparison between the selling price of the product in question and its cost of production, which would disclose the amount of the profit margin; however the Commission has not done this since it has not analyzed UBC's costs structure?

Later on, the ECJ stated the following in order to determine whether a price is excessive as to constitute a violation of article 102.a TFEU:

The questions therefore to be determined are whether the difference between the costs actually incurred and the price actually charged is excessive, and, if the answer to this question is in the affirmative, to consider whether a price has been charged which is either unfair in itself or when compared to other competing products ${ }^{10}$.

This two-step approach has become the contemporary cornerstone for considering when a price resulted so high as to be exploitative, and thus infringe article 102.a TFEU. The test consists of showing, first, that the margin between the price and the cost is excessive and, second, that the price imposed "is either unfair in itself or when compared to competing products" ${ }^{\prime 1}$. However, the notable progress of this analysis (compared with the analysis in General Motors) presents important issues that surely call for detailed analysis; for example, the idea of defining something like a price

\footnotetext{
7 General Motors, op. cit., par. 12.

8 United Brands Continental BV v. Commission EUR 207(1978). 1 CMLR 429 (1978).

9 United Brands, op. cit., pars. 250-251.

10 United Brands, op. cit., par. 252.

11 United Brands, op. cit., par. 252.
} 
that is "unfair on itself" is rather daunting. Also, the idea of being able to compare "competing products" in order to reach a decision assumes that the reference transactions are, by themselves, free from competitive concerns; such an assumption is hardly realistic. Although these two issues will be dealt more thoroughly in the next subsection, it is important to emphasize them here because of the importance the EC itself has placed on them in recent cases.

In a more recent decision, Scandlines ${ }^{12}$, the EC deployed the United Brands test and showed the extent to which its application is presents a series of difficulties that prevented the enforcement of article 102.a TFEU. The complainant, Scandlines Sverige AG, a ferry operator, complained that Helsingborgs Hamn AB (HHAB), a company responsible for running the Swedish port of Helsingborg for ferry crossings between Denmark and Sweden, had incurred in abuse of dominance by charging excessive and discriminatory port charges.

After assessing the evidence, the EC noted that even if it were possible to prove that the margin between the price of the services offered and the cost of providing them is excessive, it continues to be difficult to ascertain whether a price is unfair by comparing it with other margins and prices, even when it is possible to make such comparisons in the first place ${ }^{13}$. The difficulties stem not only from the amount of information required for this analysis, but also from considering when a margin of profit is excessive ${ }^{14}$. Thus, the report of the EC concludes its analysis of excessive pricing by stating the following:

In the light of the above, the Commission considers that there is insufficient evidence to conclude that the port charges would have "no reasonable relation to the economic value" of the services and facilities provided to the ferry-operators by HHAB, when all the relevant (economic) factors for the determination of this economic value are taken into account. (...) Hence the prices charged by HHAB under the port charges should not therefore be found unfair in themselves. (...) The Commission therefore concludes that there is not sufficient evidence that the port charges would be unfair/ excessive and that there would be an abuse of dominant position by HHAB within the meaning of Article 82 of the EC Treaty. Scandlines' complaint in this regard must therefore be rejected ${ }^{15}$.

When considered together, the General Motors and United Brands decisions suggest a rather optimistic approach to the issue of whether a price can be deemed excessive and thus unfair, to the extent that the test suggested in the latter is assumed to be able to provide precise answers in particular instances. In fact, the ECJ stated in

12 Scandlines Sverige AG v. Port of Helsingborg, Case COMP/A.36.568/D3.

13 Scandlines, Sverige $A G$, op. cit., pars. 214 and following.

14 Scandlines, Sverige $A G$, op. cit., pars. 232-233.

15 Scandlines, Sverige $A G$, op. cit., pars. 246-248. 
United Brands that "[o]ther ways may be devised - and economic theorists have not failed to think up several - of selecting the rules for determining whether the price of a product is unfair"'16. In turn, the EC's analysis in Scandlines lacks such optimism, as the conclusion of the report suggests, because of the inherent difficulties in determining the extent to which the margin between costs and prices can be deemed excessive, and if so, what constitutes a price "unfair in itself or when compared to other competing products" ${ }^{17}$.

\subsection{Can Article 102.A be Applied Consistently?}

Because of the difficulties suggested above, it has become a common place in the competition law literature to argue in favor of a restricted enforcement of article 102.a TFEU, and in some particular instances, to suggest ways in which the United Brands test can be complemented in order to provide better guidance for more precise investigation. However, a general halo of skepticism surrounds the enforcement of this provision ${ }^{18}$.

A general account of this skepticism can be found in Richard Whish's influential book on EU competition law ${ }^{19}$. In particular the idea the competition authorities become price regulators begets important observations. First, the practice of charging exploitative high prices by monopolists is a self-defeating behavior, since the returns from such practices attract competitors (given low entry barriers), which in turn increases competition and, eventually, reduces prices for consumers. In this scenario, active intervention by EU authorities is unwarranted, for the market in which the monopolist offers his products or services will eventually correct itself with the entry of new competitors. Moreover, monopolists should be allowed to set prices that enable them to undergo research and development practices, which are expensive and necessary for developing better goods and services for customers. But even if in spite of these arguments it is still considered necessary to control exploitative prices, it is necessary to craft this policy into a legal rule that can be administrable by the relevant authorities and provide businessmen with enough certainty to know the legality of their conduct. Therefore, a second observation is based on whether such a legal rule (or standard) can be cast and properly enforced by the relevant authorities. In order to do so, the enforcement authorities need to have and manage adequately important amounts of information about the market, an effort that administrative agencies can do with some difficulty, but that is considerably more difficult for courts and tribunals. As these criticisms suggest, the construction of adequate procedures for applying

16 United Brands, op. cit., par. 253.

17 United Brands, op. cit., par. 252.

18 See, for example, A. De Streel \& M. Motta, Exploitative and Exclusionary Excessive Prices in EU Law, available at: http://professorgeradin.blogs.com/professor_geradins_weblog/files/ExcessivePrices18122003.pdf. Also, Giorgio Monti, EC Competition Law, Cambridge University Press, p. 218 (2007).

Richard Whish, Competition Law, Oxford University Press, pp. 688-690 (5th ed. 2005). 
article 102.a TFEU is a matter of much importance for the adequate functioning of EU competition law.

David S. Evans and Jorge A. Padilla develop these cautious observations in a decisionbased analysis that takes into considerations the different types of errors, and their relevant social costs, that the enforcement of this article may produce ${ }^{20}$. Although they consider that a policy that could identify those prices that deviate from a competitive benchmark and punish the firms behind them would undoubtedly increase social welfare, it is unclear what the appropriate benchmark could be in actual circumstances, and in particular, in dynamic industries where investment, research and innovation are very important. Moreover, the problem also relates to how a competition agency could determine precisely whether prices are above, at the same level, or below the competitive benchmark with the information it has available ${ }^{21}$. Thus, they remark: "It is that it is very hard to say when this is the case and to quantify how much of the profits-and therefore how much of prices-are the result of monopoly rather than competitive tactics"22. Moreover, they suggest that the implementation of article 102.a TFEU suggests the following impossibility theorem: "There is no price-cost or profitability benchmarking rule that implements Article 82(a) (or its counterparts in the Member States) in a manner that satisfies the following two conditions: (a) objectivity and (b) efficiency"23.

Because of these indeterminacies of real life situations, any policy that aims at detecting and prohibiting excessive prices as perceived in actual markets is likely to produce incorrect assessments: false convictions-assessing prices as excessive when they are competitive-and false acquittals-assessing prices as competitive when they are excessive. False acquittals reduce social welfare because the output of a given product or service is lower than what is deemed optimal; false convictions reduces the profits companies have, which in turn diminishes the incentives to innovate and invest, which also harms consumers in the long run. In turn, they consider that false convictions-assessing prices as excessive when they are competitive-are potentially more harmful than false acquittals because a stringent policy regarding excessive pricing is bound to work as a upper limit to profits. Since profits are uncertain before the investments are made, firms would only invest if their expected return exceeds the costs of capital incurred, which is more likely to be deemed positive if there is no rule, such as article 102.a TFEU, that may work as a cap to expected profits $^{24}$. The ultimate reason why such type of error is more harmful than false ac-

20 David S. Evans \& Jorge A. Padilla, Excessive Prices: Using Economics to Define Administrable Legal Rules, Centro de Estudios Monetarios y FInancieros (CEMFI), Working Paper 0416 (2004).

21 David S. Evans \& Jorge A. Padilla, op. cit., p. 3.

22 David S. Evans \& Jorge A. Padilla, op. cit., p. 8.

23 David S. Evans \& Jorge A. Padilla, op. cit., p. 18.

24 David S. Evans \& Jorge A. Padilla, op. cit., pp. 23-24. 
quittals is because by limiting the expectations of profits, firms will invest less and produce less new products, which, in the long run, diminishes consumer welfare. By diminishing the expected profits, such a rule would, in turn, deprive consumers of their surplus in cases in which new products are introduced in markets and they benefit from them ${ }^{25}$. Moreover, this is specially true in industries in which firms compete for the market as a whole by offering new products and services, in emerging industries in which firms are considering whether they participate, and in other, mature industries in which technical advances allows and upgrading services; in sum, in industries in which taking risks is particularly high, there is trial and error, and the returns to success are huge ${ }^{26}$.

Therefore, Evans and Padilla conclude, the charging of prices that seem excessive should fall squarely within a presumption of legality for the purposes of enforcing article 102.a TFEU. This presumption however, should not be without rebuttal; it could be validly applied in really obvious, serious and hardly defensible cases, in which the difficulty and indeterminacy of the tests for implementing this provision would not alter significantly the validity of the conclusion reached by the competition authorities ${ }^{27}$. In particular, some particular circumstances, which have to be cumulative, warrant the application of this provision. Such circumstances are the following: 1) the firm under investigation enjoys a (near) monopoly position in the market, which is not the result of past investments or innovations, and which is protected by insuperable legal barriers to entry; 2 ) the prices charged by the firm widely exceed its average total costs, and 3) there is a risk that those prices may prevent the emergence of new goods and services in adjacent markets ${ }^{28}$.

However, not all commentators who acknowledge the difficulties in implementing article 102.a suggest such a narrow and skeptical view of its usefulness. For, as it seems rather clear from the arguments presented by Evans and Padilla, the practical consequence of this approach is to minimize to a large extent the enforcement of this article only to a sub-set of cases which are as scarce as visible and easy. However, if competition authorities could refine their analytical tools for being able to decide what counts as an "unfair price" after being able to assess the margin of profits as substantial (that is, borderline "excessive"), then they could avoid most of the pitfalls suggested by these authors in their otherwise very persuasive approach. While acknowledging the limits of enforcement posed by the volume, quality and usefulness of the information competition authorities, and the potential costs of undue enforcement, alternatives can be sought that have, as a practical consequence, a widening of the cases and situations in which article 102.a TFEU could be deployed.

25 David S. Evans \& Jorge A. Padilla, op. cit., p. 24.

26 David S. Evans \& Jorge A. Padilla, op. cit., p. 25.

27 David S. Evans \& Jorge A. Padilla, op. cit., pp. 29 and following.

David S. Evans \& Jorge A. Padilla, op. cit., p. 29. 
One interesting challenge to the argument that high prices constitute incentives for entry from possible competitors, and therefore markets in which these prices are charged can self-correct, is based on an analysis developed by Ariel Ezrachi and David Gilo ${ }^{29}$. These authors argue that the relevant price these eventual competitors take into consideration are those that result after the entry has taken place, and not the prices observed before such entry. This is so because incumbents, that is, participants who are already in the market and setting the prices observed by their eventual competitors, can cut their prices as soon as a new rival arrives, and the rivals know this. On the other hand, pre-entry prices are significant because they convey information about the productive efficiency of the actual incumbent; that is, the soon-to-be rival can eventually estimate with some accuracy the marginal costs of the incumbent. Therefore, if pre-entry prices suggest that the incumbent is inefficient when compared with the arriving competitors, the latter will enter the market, because they know that their efficiency advantage will prevent the price-cut of the incumbent from driving them outside of the market ${ }^{30}$. On the other hand, if an incumbent is more efficient than a possibly new rival, and the latter knows this, he will not enter the market, in spite of the pre-entry high prices, because he knows that a price-cut could drive him outside of the market ${ }^{31}$. As it turns out, it is not the level of prices which attracts new competitors, but rather, their capacity to face diminishing prices without sacrificing their marginal revenues, which in turn is based on the efficiency of their production. Moreover, this can be so independently of whether there is a prohibition against charging excessive prices, as long as an inefficient incumbent can charge a higher price that its efficient rival ${ }^{32}$.

The implications of the argument of Ezrachi and Gilo are rather ambiguous, since their analysis also suggests that a rule forbidding excessive and high prices will not necessarily improve or deter the conditions for entry ${ }^{33}$. Therefore, they suggest a careful, case-by-case approach, according to which competition authorities may intervene unless they belief that the prices observed in a particular sector will attract investors or cannot estimate the costs of the incumbent $t^{34}$.

As enlightening as the perspective suggested by Ezrachi and Gilo may be, this "case by case" approach requires that competition law authorities develop a systematic, procedural inquiry based on the facts before them. Pinar Akman and Luke Garrod

29 Ariel Ezrachi \& David Gilo, Are Excessive Prices Really Self Correcting?, 5. J. Competition L. and Econ. 249 (2009). The page references presented here are those of a previous version available at SSRN http://ssrn.com/ abstract $=1237802$

30 Ariel Ezrachi \& David Gilo, op. cit., p. 7.

31 Ariel Ezrachi \& David Gilo, op. cit., p. 7.

32 Ariel Ezrachi \& David Gilo, op. cit., p. 10.

33 Ariel Ezrachi \& David Gilo, op. cit., p. 17.

34 Ariel Ezrachi \& David Gilo, op. cit., p. 18. 
suggest precisely a set of analytical tools that, within an optimistic vein, could improve the accuracy of analysis undergone by competition authorities who have the difficult task of enforcing article 102.a TFEU. They do so by suggesting that the "dual entitlement principle", as developed by Kahneman et.al. ${ }^{35}$, could complement the second step of the United Brands test and improve its certainty before actual pricing decisions have been taken ${ }^{36}$. The "dual entitlement principle" states that firms and consumers are entitled to the terms of trade of a given reference transaction; hence, it is unfair for a firm to charge a price that changes the terms of the entitlement of its customers to acquire a gain for itself ${ }^{37}$.In particular, people consider that a price is unfair if it is higher than the reference transaction due to the exploitation of market power, because the firm obtains a benefit at the expense of its customers. Moreover, it's the fact that there is a change, rather than the magnitude of the change itself, that is perceived as unfair ${ }^{38}$. Also, this principle is consistent with the possibility that a price is not unfair if its level is higher than past the level of the reference transaction due to higher production costs, even when the extra costs are assumed entirely by the customers ${ }^{39}$. Finally, this principle is also consistent with the possibility that a firm maintains its current price level in spite of the fact that it has reduced its own production costs, and therefore is able to increases its margin of profits without increasing the price customers pay ${ }^{40}$. Thus, the dual entitlement principle is ample enough to allow a firm to increase its profits because of the efforts in investment and research it has undergone, and to allow an increase in price when the factors of production have increased, while, consistently, condemns price increases that take place solely as a consequence of sheer market power. Because of these elements, it posits as an adequate candidate for contributing to incrementing the precision of a procedure for applying article 102.a TFEU consistently ${ }^{41}$.

After presenting the main relevant aspects of the dual entitlement principle, Akman and Garrod narrow down its abstract features in order to suggest how a procedure for applying article 102.a TFEU could proceed. This procedure, built upon the United Brands test, assumes that the first part of the test suggests that there is a substantial difference between the costs and the price charged; thus it only aims at determin-

35 Daniel Kahneman, Jack L. Knetch \& Richard Thaler, Fairness as a Constraint on Profit Seeking: Entitlements in the Market, 76 Am. Econ. Rev. 728 (1986). This paper publishes a study conducted by the authors based on a telephone survey in three states of the United States, in which the respondents were asked how they assessed a particular change in prices given that a contractor (a firm, a tenant, or an employer) changed their pricing behavior when compared to a predetermined reference transaction.

36 Pinar Akman \& Luke Garrod, When are Excessive Prices Unfair?, CCP Working Paper 10/04 (March 2, 2010), available at SSRN http://ssrn.com/abstract=1578181.

37 Daniel Kahneman, Jack L. Knetch \& Richard Thaler, op. cit., pp. 729-730.

38 Daniel Kahneman, Jack L. Knetch \& Richard Thaler, op. cit., p. 735.

39 Daniel Kahneman, Jack L. Knetch \& Richard Thaler, op. cit., p. 733.

40 Daniel Kahneman, Jack L. Knetch \& Richard Thaler, op. cit., p. 734.

41 Pinar Akman \& Luke Garrod, op. cit., p. 2. 
ing whether a price "is either unfair in itself or when compared to other competing products" $"$. Its first step considers whether the terms of trade are sufficiently close to those of the reference transaction, which, the authors suggest, should be the past level of prices of the firm under investigation ${ }^{43}$. It the actual price levels are close to those of the reference transaction, the price itself would not be considered unfair under the aforementioned provision. If, however, they are not, then a second step considers whether the firm's profits are considerably larger than those of the reference transaction. If they are not, again the price should not be considered unfair. If they are, on the other hand, the price might be a violation of the dual entitlement principle because it may well be a consequence of the firm's market power, but it may also be due to an increment in the costs of the production factors. Thus, a third step is required, which delves into the causes of the price increase; if this is due to a lack of competition in the relevant market, than the price can be considered as unfair according to article 102.a TFEU ${ }^{44}$. Besides the advantages this test has in terms of translating abstract notions of fairness in markets to a workable, practical procedure for implementing competition law, it also provides ex ante certainty to firms who may be subject to investigations and, just as important, provides a clear definition of what counts as an unfair price ${ }^{45}$.

In spite of the efforts suggested by Akman and Garrod, it is to be expected that article 102.a TFEU will continue to be applied sparsely by the EC, and that the ECJ (or the Court of First Instance) will hold its ground regarding the type of analysis required to levy a penalty for excessive and unfair pricing successfully under EU law. From the perspective of the competition authorities of jurisdictions that adopted provisions similar to this article, this conclusion is problematic. The members of these competition authorities are highly aware of the discussions that take place in those jurisdictions that, like the United States and the EU, are taken to be leaders in these matters. Just as well, they follow recent developments that take place in those jurisdictions, and try to implement them in their own jurisdictions. In light of the previous discussion about article 102.a TFEU, these individuals may wonder: why did we bother to adopt a provision which has been subject of the skepticisms and doubts mentioned above? Notwithstanding these reasons, this article suggests that the effort has not been in vain, and that the enforcement of these provisions can be done objectively and taking into account considerations of legitimacy and, to a certain extent, efficiency.

42 United Brands, op. cit., par. 252.

43 Pinar Akman \& Luke Garrod, op. cit., pp. 13-14. They do so for two reasons; first, because it enables comparison of how much the price has changed due to lack of competition, and second, because the comparison will be more accurate vis a vis other products developed by the firm or the prices charged by other participants or in similar markets. 


\section{Two Perspectives on Competition Law in Developing Countries ANd Their USEFulness for ENForcing ExCESSIVE and Unfair Price Provisions}

The discussions about the possibilities of adequately enforcing article 102.a TFEU or similar provisions by competition authorities in developing countries are just a part of a much bigger scenario of discussions and dialogues between different perspectives which hold different and, sometimes, opposing views about fundamental aspects of competition law. A closely related field that shows similar manifestations of difference is the advance of competition law itself in developing countries. Here, we can also find different perspectives. A first perspective advocates a decidedly welfarist approach to competition law, and therefore argues in favor of considering efficiency the primary goal of competition law in developing jurisdictions. A second perspective advocates a different approach, focusing more on values related with distributional concerns and fairness. As can be expected, from each of these perspectives we could reach different, and to some extent, opposing conclusions on whether developing countries should enforce their excessive and unfair price provisions. Therefore, knowing better what these perspectives are about is relevant to our discussion because it provides us with insights that might be useful for considering how should competition law authorities in developing countries enforce their provisions that resemble article 102.a TFEU.

\subsection{Consumer Welfare and Particular, Stylized Traits of Developing Countries}

As mentioned above, one particular emphasizes a particularly welfarist approach to the development of competition law in developing countries. Based on sound economic analysis, Michal Gal suggests that the key trait in developing countries ("small economies") is that, due to the size of their markets, they are unable to host a relatively large number of firms that reach minimum efficient scales of production or "MESP") relative to demand ${ }^{46}$. This produces an important set of consequences that are relevant to the industrial policies followed and, specifically, for competition law enforcement. First, large MESP relative to demand produces higher industrial concentration levels for developing countries than for developed ones. In particular, depending on its demand, a given market may only sustain a small limited number of firms or, on some cases, give place to a natural monopoly ${ }^{47}$. Thus, as it turns out, developing countries can sustain a rather limited number of local firms when compared to its demand, which in turn implies that these firms will have some market

46 Michal Gal, Size Does Matter: The Effects of Market Size on Competition Policy, 74 U. of S. Cal. L. Rev., 1437 (2001).

47 Ibíd., pp. 1446-1447. 
power. Second, large MESP relative to demand constitutes one of several entry barriers that actual and eventual competitors may face. Just as well, the fact that there is vertical integration within specific sectors that face large MESP relative to their demands increases entry costs for eventual competitors ${ }^{48}$. Third, developing countries with small markets face suboptimal levels of production, mostly due to production facilities that are nor specialized nor large enough to achieve economies of scale and other advantages that stem from specialization. This is reinforced by market concentration; since there are only a very limited number of firms on the markets, and each holds certain market power, they become interdependent, and may choose to reduce the intensity of their rivalry, especially if becoming more aggressive is not rewarded because cost savings can not be passed on to consumers ${ }^{49}$. Therefore, these conditions give place to the following dilemma: "Small size sharpens the dilemma between whether an economy would be better off with higher concentration to permit more efficient scales of activity or with lower concentration for better allocated efficiency through competition"

The presence of this conditions, suggests Gal, produce the particular conditions competition authorities in developing countries face; an optimal competition policy should take these local conditions into account in order to devise an adequate enforcement of its provisions ${ }^{51}$. Doing so requires policy choices at different levels. One which Gal places much emphasis on is the primacy of efficiency over other social goals and principles -like protecting small businesses or "national" champions-that may inform competition policy. The main reason for this is that developing countries with small markets "are less able than their larger counterparts to afford a competition policy economic efficiency for broader objectives" $" 52$. To leave aside economic efficiency as the paramount goal of competition policy runs the risk of taking decisions that harm consumers, and requires such systemic efforts that results in imposing intolerably high costs to the economy as a whole ${ }^{53}$. Besides, this would deprive firms of incentives for investing in their own growth ${ }^{54}$, and would place judges and competition agencies in positions in which they would engage in political decision-making "for which there are no appropriate legal criteria, and in a costly regulatory/supervisory role for which they are ill-equipped"55. Finally, Gal contends, to consider whether non-efficiency oriented economic goals should have a place in competition law opens the door for rent-seeking efforts by local actors that may benefit from a com-

48 Michal Gal, Size Does Matter: The Effects of Market Size on Competition Policy, op. cit., pp. 1447-1448.

49 Michal Gal, Size Does Matter: The Effects of Market Size on Competition Policy, op. cit., pp. 1448-1449.

50 Michal Gal, Size Does Matter: The Effects of Market Size on Competition Policy, op. cit., p. 1450.

51 Michal Gal, Size Does Matter: The Effects of Market Size on Competition Policy, op. cit., pp. 1450-1451.

52 Michal Gal, Size Does Matter: The Effects of Market Size on Competition Policy, op. cit., p. 1451.

53 Michal Gal, Size Does Matter: The Effects of Market Size on Competition Policy, op. cit., p. 1451.

54 Michal Gal, Size Does Matter: The Effects of Market Size on Competition Policy, op. cit., p. 1451-1452.

55 Michal Gal, Size Does Matter: The Effects of Market Size on Competition Policy, op. cit., pp. 1452. 
petition policy that provides safe harbors to uncompetitive behaviors ${ }^{56}$. Therefore, she concludes, developing countries should allow little or no weight to non-efficiency considerations when devising and implementing their competition policies ${ }^{57}$; as it turns out, this implies that high industrial concentration levels are a necessary evil with which this countries should contend, and that competition law analysis should balance the anticompetitive and pro-competitive aspects of a given $\operatorname{conduct}^{58}$.

Gal's analysis applies as well to excessive and unfair price provisions that may be in developing countries' competition laws. Not surprisingly, to establish a provision that states that prices are illegal if they are excessive and unfair, and to enforce it, may limit dynamic competition drastically. This implies affecting negatively firms' incentives to innovate and invest in developing their local capacities, which in turn harms consumers by depriving them of the surplus that results from being able to find new products. In other words, Gal's arguments seem to be wholly consistent with the approach presented by Evans and Padilla, presented above. Moreover, these authorities do not only have to face the theoretical issues mentioned in the previous section, they also have to do so while facing unique conditions that authorities of other countries do not, typically, their lack of both financial and human resources, as well as their relative dependence vis a vis other branches of government. Therefore, it is undesirable that competition authorities in developing countries enforce such provision. Moreover, in a different paper ${ }^{59}$, in which she analyzes the reception of article 102.a TFEU in Israel, she presents it as an unintended consequence of transplanting article 102 TFEU entirely. In light of the issues derived from its enforcement in the EU commented above, she also argues that if the Israeli congress would have had the chance to debate more thoroughly the adoption of this provision, it would have had the opportunity to consider solutions to the problems it pose ${ }^{60}$.

\subsection{Unfair Pricing as a Manifestation of Abuse of Dominance and the Factual Conditions of Developing Countries}

An efficiency driven competition policy for developing countries seems to be a reasonable and achievable goal in terms of how competition law could contribute to development. However, the particular conditions that developing countries face may manifest in particular instances in which the general approach suggested by Gal in the article reviewed before would be undesirable, even from a perspective

56 Michal Gal, Size Does Matter: The Effects of Market Size on Competition Policy, op. cit., p. 1452.

57 Michal Gal, Size Does Matter: The Effects of Market Size on Competition Policy, op. cit., p. 1452.

58 Michal Gal, Size Does Matter: The Effects of Market Size on Competition Policy, op. cit., p. 1453.

59 Michal S. Gal, The 'Cut and Paste' of Article 82 of the EC Treaty in Israel: Conditions for a Successful Transplant, NYU Law and Economics Research Paper, 08-03, available at SSRN http://ssrn.com/abstract=1082035.

60 Michal S. Gal, The 'Cut and Paste' of Article 82 of the EC Treaty in Israel: Conditions for a Successful Transplant, op. cit., pp. 15-16. 
that embraces efficiency. In particular, there are other conditions, besides MESP and its consequences, that haunt developing countries and that are closely related to it. In particular, I refer to political and idiosyncratic conditions that through time have shaped, not necessarily to the best interests of the population, the economic structure of the markets found in developing countries. These conditions combine with economic factors, like the availability of resources, and give place to conditions in which abuse of dominance can be exercised, and which could be tackled by competition law provisions, including those that prohibit excessive and unfair prices.

Phillipe Brusick and Simon J. Evenett offer a review of conditions and particular instances that developing countries face and that give place to abuse of dominance, and, in some cases, charging unfair and excessive prices ${ }^{61}$. Some of these conditions depend upon a mixture of geographical circumstances and poor infrastructure ${ }^{62}$, as well as by the size of their market itself ${ }^{63}$. One particular type of abuse reported is exercised directly by the State itself, via, for example, its tradition not to pay for the public utilities provided to its different institutions, even after these have been privatized $^{64}$. In other cases, the abuse committed by the State is done when it is in charge of providing the utilities to the public itself, in fields like electricity, telecommunications and banking ${ }^{65}$. A closely related type of abuse occurs in fields in which participants are monopolists after privatization processes have taken place, especially if they receive long term permits to operate as monopolists. Although developing States usually mount regulatory agencies in charge of controlling the exercise of market power of these monopolists, these are prone to capture by the utility they regulate in the first place ${ }^{66}$. This type of abuse occurs, for example, after the privatization of infrastructure like ports has taken place ${ }^{67}$, as well as in cases related with essential facilities related to telecommunications ${ }^{68}$. However, this kind of abuse is not exclusive of concession-granted monopolies. In developing countries in which multinational firms compete with local firms, the former may easily establish dominant positions because of their revenues and their deep pockets, when compared with the latter's.

61 Philippe Brusick \& Simon J. Evenett, Should Developing Countries Worry about Abuse of Dominant Power?, 2008 Wis. L. Rev., 269 (2008).

62 Ibíd., pp. 274-275.

63 Ibíd., p. 276 (referring especially to banking and financial activities).

64 Philippe Brusick \& Simon J. Evenett, op. cit., pp. 277-278.

65 Philippe Brusick \& Simon J. Evenett, op. cit., p. 280.

66 Philippe Brusick \& Simon J. Evenett, op. cit., p. 281.

67 Philippe Brusick \& Simon J. Evenett, op. cit., pp. 281-282. For example, as a consequence of the privatization of a large port facility in Zambia, it was founded that the company managing this facility was giving special price and non-price advantages to a subsidiary transportation company it owned; in turn, the competition authorities could not carry on a remedy procedure because the Zambia's Fair Trading Act exempted the application of its provisions in which the government was party, and the government was a party to the concession. This case has important similarities with the Scandlines case discussed above.

Philippe Brusick \& Simon J. Evenett, op. cit., pp. 283-284. 
Such types of abuses include, for example, the ones faced by local diary producer and suppliers in the hands of large multinational retail stores, like Carrefour and Tesco ${ }^{69}$. But perhaps the most noteworthy type of abuse denounced is the one relating to patent prices in the pharmaceutical sector. Since patent owners can restrict parallel imports to some extent, the question is to what extent they can prevent buyers from abroad to arbitrage and sell their products in a given market at lower prices than they offer $^{70}$. This issue is of particular importance in developing countries in which the possibility of generic, low cost medicines could contribute to alleviating public illnesses, like AIDS $^{71}$.

The considerations brought forth by Brussick and Evenett appeal to a wider set of considerations, mainly those related with the proper design of competition authorities and their relative independence vis a vis other branches of power, and especially, the executive branch. In a different article, Gal herself acknowledges the importance of taking into consideration the different political forces that pull in different directions regarding antitrust enforcement, as well as the institutional settings that can be taken into consideration for harnessing them unto productive results ${ }^{72}$. In particular, she suggests that certain institutional settings should be taken into consideration for such a purpose, like the independency of the competition authorities, both political and budgetary, judicial review of its decisions, and even the criminalization of certain practices $^{73}$. Moreover, certain compromise between efficiency and other principles and values can be obtained, only to the extent that "the basic principles of a market driven by competition are not seriously harmed and where the gain to broader policy goals is significantly larger than the harm to competition"74. In situations like the one mentioned above related with the pharmaceutical sector, in which the lives of millions of people are a stake, this compromise could hold even for enforcing provisions related with excessive and unfair prices.

It remains unclear, however, to what extent the different political forces in developing countries would allow competition policy to go as far as this statement suggests. Instead, the history of competition law in different jurisdictions seems to have evolved into the sort of system that displays the institutional arrangements that Gal identifies, rather than simply emerging or becoming into existence with them already in

69 Philippe Brusick \& Simon J. Evenett, op. cit., pp. 284-285.

70 Philippe Brusick \& Simon J. Evenett, op. cit., p. 285.

71 Philippe Brusick \& Simon J. Evenett, op. cit., p. 285.

72 Michal Gal, Reality Bites (or Bits): The Political Economy of Antitrust Enforcement, New York University Law and Economics Working Papers, paper 57 (2006), available at http://lsr.nellco.org/nyu_lewp/57.

73 Michal Gal, Reality Bites (or Bits): The Political Economy of Antitrust Enforcement, op. cit., pp. 6-10.

74 Ibíd., p. 11. 
place ${ }^{75}$. Therefore, the question is about which conditions shape a given competition law system, imbedded within a given political and legal system, can evolve into a system that exhibits these traits, and whether enforcing a provision similar to article 102.a TFEU can contribute to such evolution.

In light of these considerations, it becomes completely relevant to ask whether competition law in developing countries should embrace technical questions, like issues related with minimum efficient scales of production, as its foundational principles or goals, or if they should take into consideration the political conditions that allow precisely the abuses of dominance Brusick and Evenett consider. Eleanor Fox asks precisely that question when considering the different alternatives developing countries have regarding the design and enforcement of their competition law regimes ${ }^{76}$. After all, that State interventions in markets may distort prices and prevent efficient transactions is one part of the story; that State interventions are particularly problematic in developing countries because policy making tends to be less visible, more concentrated, and more centralized is the second half. Moreover, these considerations are of the most relevance since, Fox argues, most developing countries show certain distrust for liberalization policies that, based on the ideas of the Washington Consensus, because of their allegedly tendency to advantage those parties that already have an advantage to begin with ${ }^{77}$.

Based on the work of Hernando de Soto ${ }^{78}$. Fox argues that competition law can harness the forces of markets and use them as a ladder for social mobility of the population. Practices that restrict competition are harmful not only because they are inefficient, they also constitute barriers for letting individuals have access to the benefits of markets, including better wages and the possibility of joining formal, legal markets, instead of developing activities at the margin of the law. In turn, most of these practices that constitute barriers for social mobility via the way markets work are, in many ways, the result of how markets work. This is so because the State imposes conditions related with red tape, delays in answering permissions and other conditions that constitute incentives for productive and economically valuable activities in informal markets ${ }^{79}$. Thus, competition law may indeed have significance apart of the goals and principles related with efficiency, and not necessarily promoting enforcement against certain practices that are forbidden and harm consumers is something to be frowned upon, even when the justification for doing so is not based on economic efficiency,

75 As suggests the history of EU competition law. See David J. Gerber, Law and Competition in Twentieth Century Europe: Protecting Prometheus, Oxford University Press (1998).

76 Eleanor M. Fox, Economic Development, Poverty and Antitrust: The Other Path, 13 Sw. J. L. and Trade Am. 211 (2006-2007).

77 Eleanor M. Fox, op. cit., p.105.

78 In particular, Fox refers to Hernando De Soto, The Other Path: The Invisible Revolution in the Third World, Harper and Row (1989).

79 Eleanor M. Fox, op. cit., pp. 112-114. 
but not necessarily runs against $i^{80}$. The key issue remains, however, to identify the key principles and the institutional settings that underlie them. However, enforcing the applicable provisions may in turn imply not accepting particular developments that take place in developed jurisdictions ${ }^{81}$. In particular, regarding excessive prices, Fox argues that if the competition authorities in developing countries have the resources and the independence for enforcing the relevant rules, what are needed are interventions that are "early triggered" and that result from previous policy choices about the sort of interventions competition law that is to be enforced ${ }^{82}$.

\subsection{Are the Stylized Traits and Factual Conditions OpPosite or Complementary?}

So far, two positions have been sketched about how to assess the enforcement of provisions similar to article 102.a TFEU in developing countries. As mentioned above, two perspectives can be identified: A first perspective advocates a decidedly welfarist approach to competition law, and therefore argues in favor of considering efficiency the primary goal of competition law in developing jurisdictions. A second perspective advocates a different approach, focusing more on values related with distributional concerns and fairness. Based upon the arguments that were suggested regarding the first perspective, it can be concluded that developing jurisdictions should not enforce any provision of their competition law regime that punishes excessive and unfair prices. On the other hand, based upon the arguments that were suggested regarding the second perspective, it can be concluded that developing countries should enforce such provisions, if they have the capabilities to do so independently, and if pursues values that are concomitant with economic efficiency (like social inclusiveness as a proxy for increasing both supply and demand in a given market).

At first glance, it seems that these two perspectives are at odds with one another, precisely because of the different conclusions that they can reach on a specific topic like the one discussed here. However, a more detailed analysis would suggest that they are complementary, in the sense of being mutually reinforcing by contributing complementary elements to the analysis of these particular topic. In particular, welfarist approaches like the one discussed above are of the uttermost importance because they provide interesting analytical and theoretical elements that are useful for better assessing the economic role of competition law and its enforcement. By doing so, they provide a rich framework for assessing what sort of enforcement can be counterproductive when considered from the theoretical elements that constitute

\footnotetext{
80 Ibíd., p. 119.

81 Ibíd., p. 119.

82 Ibíd., p. 120.
} 
present-day competition law analysis. Just as well, the analysis presented by Eleanor Fox is more oriented to developing certain awareness of the context, political, legal and social that surrounds competition law enforcement, and how it relates to goals (like the Millennium Development Goals, or "market inclusiveness") that provide strength for adopting and enforcing competition law provisions in the first place. Moreover, the rather painful certainty that these contexts produce institutional arrangements that are not to the benefit of the population, as suggested by the description of the work of Brussick and Evenett, discussed above, also shows the importance of enforcement. Therefore, while the welfarist approach contributes to the debate by providing the analytical tools that should guide competition law enforcement according to well established parameters, the second perspective appeals to the need of a competition law enforcement that "fits" within a social context determined by aspirations and goals as well as by the need to address harmful competitive practices that take place on a regular, day to day basis. It is with these considerations in mind that, in the next section, we argue in favor of enforcing competition law provisions that deal with excessive and unfair prices.

Another way in which we can see how the different perspectives discussed in previous sections complement each other is by comparing the analysis of Evans and Padilla regarding the difficulties for rationally and efficiently enforcing article 102.a TFEU with the pervasive instances of abuse of dominance recorded by Brussick and Evenett. As it turns out, these two pairs of other offer different analysis about the institutional arrangements that bring forth abuse of dominance, and in particular, the charge of excessive and high prices. While the former observe that abuse of dominance in developing countries results from past State interventions, the latter seem to only consider market power that results strictly from past decisions by the firms in the markets. Because of the pervasiveness of the role of the State and the economic structure of markets in developing countries, there is a much higher probability of finding the sort of cases that Evans and Padilla consider to be exceptional in the markets of more developed jurisdictions, and which are suitable for enforcement under the mentioned provision. Hence, the positions suggested by these two pair of authors seem more like complementary, or at least, not at odds with each other, than what can be thought of at first glance.

\section{Enforcing Provisions Against Excessive and Unfair Prices: The Yacimientos Petroliferos Fiscales and Mittal Steel CASES}

As I was doing my research for this article, I stumbled upon a study done by María Coppola Tineo and Rusell Pittman, two members of the Antitrust Division of the 
American Department of Justice, about abuse of dominance in L.A. ${ }^{83}$. Their study is very relevant because it shows that, contrary to the warnings against over-enforcement of abuse of dominance provisions, the decisions of L.A. competition authorities have been rather sparse and limited to particular sectors, among other factors. The fear of populism via competition law enforcement appears to have been rather exaggerated, especially because the number of decisions has been limited and properly focused ${ }^{84}$. Notably, most of the enacted competition laws in this region have explicit prohibitions against charging excessive and unfair high prices, which in turn produced only one investigation and conviction between 2001 and $2003^{85}$. This is particularly interesting, since most of the countries in this region have become prominent destinations of foreign investment in recent years ${ }^{86}$.

This suggests that, contrary to what has been the rule in other sectors, populism via competition law enforcement has not been the rule in L.A. Different commentators attribute other sort of malaises to this region's competition law regimes, like excessive formalism (due to legal origin) ${ }^{87}$, inadequate attention to particular details of how markets work, and such ${ }^{88}$. This landscape, however, seems to be changing importantly, precisely because of the relevance that competition law authorities have been acquiring in their given contexts ${ }^{89}$. As a matter of fact, some of the region's competition law authorities are today among the world's best ranked competition law authorities ${ }^{90}$.

In spite of these considerations, cases regarding the charge of excessive and unfair prices remain scarce. One particular case in the region that drew much attention was that of the Comisión Nacional de Defensa de la Competencia (CNDC) against a recently privatized oil and gas company, called Yacimientos Petroliferos Fiscales (YPF). The proceedings were initiated in 1999 by the CNDC after it studied the market for Liquid Petroleum Gas (LPG), a common fuel for domestic use, and found that, between 1993 and 1997, YPF discriminated between domestic and export markets;

83 María Coppola Tineo \& Russel Pittman, Abuse of Dominance Enforcement under Latin American Competition Laws, Economic Analysis Group Discussion Paper, available at: www.justice.gov/atr/public/eag/221878.htm.

84 María Coppola Tineo \& Russel Pittman, pp. 5-10.

85 Ibíd., pp. 14-15.

86 See The Economist, Nobody's backyard Latin America's new promise —and the need for a new attitude north of the Rio Grande (Sept. 9, 2010), available at http://www.economist.com/node/16990967.

87 A. E. Rodriguez, Does Legal Tradition Affect Competition Policy Performance?, 21 Intl. Trade Jnal., 417 (2007).

88 Ignacio De León, Latin American Competition Law and Policy: A Policy in Search for Identity, Kluwer Law International (2001). Ignacio De León, An Institutional Assessment of Antitrust Policy The Latin American Experience, Kluwer International (2009). Also Bruce M. Owen, Competition Policy in Latin America, Stanford Law and Economics Olin Working Paper, 268 (October 2003), available at SSRN: http://ssrn.com/abstract=456441.

89 See Eleanor M. Fox \& D. Daniel Sokol (eds.), Competition Law and Policy in Latin America, Hart Publishing (2009).

90 Regarding Brazil, see Competition Law and Policy in Brazil: a Peer Review, available at http://www.oecd. org/dataoecd/4/42/45154362.pdf. Regarding Chile, see Chile - Peer Review of Competition Law and Policy, available at http://www.oecd.org/dataoecd/43/60/34823239.pdf. 
while consumers in domestic markets suffered from a steady increase of prices, the prices at the export markets remained stable. This practice violated article $1^{\circ}$ of Act 22.262 of 1980 (the enforceable competition law at that time), which forbade acts and practices that amount to an abuse of dominance ${ }^{91}$. In order to maintain this price discrimination, YPF included clauses in some of its contracts with its buyers that prohibited the importation of the LPG sold to them back into Argentina. Also, this company held a comfortable dominant position in the nation-wide supply of LPG and in most of the stages of production and supply, including refinement and transportation. Finally, entry of new rivals was considered difficult by CNDC, and imports were not a significant constraint for this company or for the other, much less significant producers.

After establishing these elements, the CNDC ordered YPF to cease discriminating between domestic and export markets, and to drop those contract clauses that prevent imports of the LPG it sold across its borders. Regarding sanctions, the CNDC recommended the imposition of a USD 109.644.000 fine. CNDC's recommendation was accepted by the Secretariat for Industry, Commerce and Mining, which imposed the fine $^{92}$. YPF challenged this decision, and it was upheld by an administrative tribunal regarding economic law issues; this decision, in turn, was also challenged via a special procedure, and once again was upheld by the Supreme Court of Argentina in $2002^{93}$.

As expected, this decision drew many negative reviews from commentators, most of them with an antitrust/competition law background, who criticize this decision based precisely on the sort of arguments previously mentioned in the previous sections of this article. One particular group of commentators, Lucas Grosman and Tomás Serebrisky, refer precisely to the chilling effects of the analysis exhibited in these proceedings in terms of innovation and investment, and therefore conclude that this decision makes bad law ${ }^{94}$. Notably, however, their analysis does not take into consideration that YPF, although established as a privately-held enterprise since 1992, was in fact State-owned, funded and operated before its privatization took place and at the time the events that gave place to the investigation conducted by CNDC took place. This particular aspect provides an interesting insight for explaining YPF's dominant position in the different activities related to the production and expendi-

91 The text of article $1^{\circ}$ of Act 22.262 of 1980 is the following: "Están prohibidos y serán sancionados de conformidad con las normas de la presente ley, los actos o conductas relacionados con la producción e intercambio de bienes o servicios, que limiten, restrinjan o distorsionen la competencia o que constituyan abuso de una posición dominante en un mercado, de modo que pueda resultar perjuicio para el interés económico general".

92 República de Argentina, Resolución del Secretario de Industria, Comercio y Minería № 189 de 22 de marzo de 1999.

93 República Argentina, Corte Suprema de Justicia de la Nación en autos, Recurso de hecho deducido por Yacimientos Petroliferos Fiscales S.A. en la causa Yacimientos Petroliferos Fiscales S.A. s/ Ley 22.262- Comisión Nacional de Defensa de la Competencia - Secretaría de Comercio e Industria, 2 de julio de 2002.

94 Lucas Grosman \& Tomás Serebrisky, El abuso explotativo y la defensa de la competencia en Argentina, 16 Boletín Lat. de la Competencia, 15, pp. 21-22 (2003). 
ture of LPG, both in the domestic and import markets; it is rather hard to challenge a state-sponsored company posing as a regular market participant. The analysis that can be properly applied to study abuse of dominance by regular market participants hardly seems fit to analyze the behavior of companies like YPF. However, Grossman and Serebrisky are probably right when they argue that this case reveals the need to better understand and asses the regulatory environment under which companies who apparently engage in anticompetitive behavior operate ${ }^{95}$.

A second much commented case is that of Mittal Steel in South Africa ${ }^{96}$. This country's competition regime stands out when compared with the regime of most jurisdictions because of the importance it places on non-economic goals. Section 2 of Chapter 1 of the 1998 Competition Act states the following:

The purpose of this Act is to promote and maintain competition in the Republic in order -

(a) to promote the efficiency, adaptability and development of the economy;

(b) to provide consumers with competitive prices and product choices;

(c) to promote employment and advance the social and economic welfare of South Africans;

(d) to expand opportunities for South African participation in world markets and recognise the role of foreign competition in the Republic;

(e) to ensure that small and medium-sized enterprises have an equitable opportunity to participate in the economy; and

(f) to promote a greater spread of ownership, in particular to increase the ownership stakes of historically disadvantaged persons.

In turn, section $8(\mathrm{a})$ refers to abuse of dominance in the following terms:

It is prohibited for a dominant firm to -

(a) charge an excessive price to the detriment of consumers; $(\ldots)$

Moreover, Section 1(vii) of Chapter 1 offers a definition of what constitutes an "excessive price" for the purpose of the provisions contained in the Competition Act in the following terms:

(vii) 'excessive price' means a price for a good or service which -

(au) bears no reasonable relation to the economic value of that good or service; and

(bb) is higher than the value referred to in subparagraph (us);

95 Lucas Grosman \& Tomás Serebrisky, op. cit., pp. 22- 23.

96 South African Competition Tribunal, Harmony Gold Mining Co. v. Mittal Steel S. Afr. Ltd. (Mar. 27, 2007), available at http://www.icn-capetown.org.za/comptrib/comptribdocs/97/13CRFeb04.pdf. Remanded for revision by South African Competition Appeal Court, Mittal Steel S. Afr. Ltd. v. Harmony Gold Mining Co. (May 29, 2009), available at http:/www.comptrib.co.za/assets/Uploads/Case-Documents/70CACApr07.pdf. 
In the Mittal Steel decision, the South African Competition Tribunal (SACT) found that Mittal Steel South Africa Ltd. (MS) had charged excessive prices for its steel to the detriment of its domestic consumers. In order to reach this conclusion, the SACT first established that MS enjoyed a position of "super-dominance" in the relevant market, without which excessive pricing would not have been possible. In turn, such an advantage was due to especial structural advantages this company benefited from, like having a market share of about $100 \%$ and therefore price at levels beyond those of a merely dominant firm ${ }^{97}$. Moreover, rather than concentrating on price levels, the SACT held that the key issue were the market conditions that allowed for charging the prices themselves ${ }^{98}$. These conditions were reinforced by a set of provisions MS that allowed it to prevent re-importation of the steel sold to external markets into the domestic ones ${ }^{99}$.

The SACT decision was remanded by the Competition Appeal Court of South Africa (CACSA). This Court rejected the strictly structural approach taken by the SACT, stating not only that the concept of "super-dominance" holds no grounding on the wording of the Competition $\mathrm{Act}^{100}$, but that price level analysis, like the one undergone by the EC in the cases mentioned before, was necessary in order to properly follow the provisions of the $\mathrm{Act}^{101}$. Hence, the CACSA stated that the facts of the case should be considered under these considerations ${ }^{102}$.

In spite of the obvious differences, there are some interesting similarities between the facts that brought forth the YPS and MS decisions, which are important for considering the proper application of the aforementioned legal provisions. First, neither enterprise obtained their position in their local markets by ingenious investment and research; rather it resulted from a market power entrenched by past government interventions ${ }^{103}$. As mentioned before, YPF was a state sponsored enterprise during the time in which it incurred in illegal practices; MS, on the other hand, had been privatized in 1989, when it was named South African Iron and Steel Industrial Corporation (ISCOR). After a series of transactions, ISCOR changed its name to Mittal Steel S.A., and on 2006 it merged with Arcelor, which controls it entirely. Moreover, this company benefited from particular benefits given by the government after its privatization ${ }^{104}$. Second, both YPF and MS had enough market power to prevent their own customers from arbitraging their produce and therefore prevent these companies

97 See Tribunal Decision, supra, par. 90-121.

98 Tribunal Decision, op. cit., par. 142.

99 Tribunal Decision, op. cit., pars. 182-184.

100 See Appeal Court Decision, supra, 90, par. 32.

101 Appeal Court Decision, op. cit., par. 32.

102 Appeal Court Decision, op. cit., par. 75.

103 Tribunal Decision, op.cit., par. 103.

104 These interventions did not end with Iscor's privatization; the South African government established other investment-oriented benefits from which this company benefited, like exportation Schemes (the General Export 
from successfully charging high prices. YPF had contractual provisions that barred its customers from importing and re-selling LPG to Argentinian consumers; MS had a complex arrangements of contractual provisions and rebate programs that allowed this company to segment domestic and export markets to its advantage ${ }^{105}$. Further research could determine if the combination of these two elements are recurring in cases regarding abuse of dominant positions in developing countries.

Acknowledging that these sort of practices by YPF and MS take place, and that they are harmful from different perspectives including static and dynamic efficiency, just shows the extent to which the rather "exceptional cases" considered by Evans and Padilla are much more common in developing countries than what we can consider in first place. Moreover, it shows that past public policy decisions determine a country's capacity to develop MESP, to the extent that they are closely related. Clearly, an industry's MESP depends not only on the available resources, but also on the institutions that determine how they are used. These institutions include political and economic arrangements regarding the exercise of power, both private and public, via public policy programs. Therefore, a competition policy that focuses only on whether it should punish a particular behavior based on technical, MESP-oriented perspective would be unduly narrow, and would fail to take into consideration the exercise of market power that derives from an entrenched position due to past state interventions ${ }^{106}$. This is not an argument for rejecting efficiency only, MESPoriented perspectives; rather it simply shows that some abuse of dominance cases involving exploitative behavior can be better understood going beyond the scope of narrow efficiency analysis.

\section{Conclusion: The Uneasy Case for Enforcing Competition Law Provisions Related with Excessive and Unfair Prices in Developing Countries}

The charge of excessive and unfair prices is the typical offense of monopolies; it is the most obvious form of social harm that can be done by a monopolist, since it diminishes overall welfare and gives place to a transfer of wealth between consumers and the monopolist (assuming in both cases, that the monopolist has been able to outmaneuver competition, and this is not always the case). However, in many cases, like those related with the privatization of infrastructure, monopolies are born this way. And even when this may be the case, competition law is not the legal regime that

Incentive Scheme) and a accelerated depreciation allowance provision (section 37E of the Income Tax Act) in the applicable tax laws, among others.

105 Tribunal Decision, op.cit, pars. 182, 184.

106 Ariel Ezrachi \& David Gilo, op.cit., have provided a particular analysis that incorporates these considerations regarding the Mittal Steel case. See Ariel Ezrachi \& David Gilo, Excessive Pricing, Entry, Assessment, and Investment: Lessons from the Mittal Litigation, 76 Antitrust L. Jnl., 873 (2010). 
may address the issues related with competition, for there may be other incumbent authorities. Thus, assessing whether a competition law authority from a developing country should enforce a provision related with excessive and unfair prices should take into consideration many relevant factors when doing so. Are there other incumbent authorities? Are they better suited (in terms of access to information, resources, political independence) for investigating and punishing excessive and unfair prices? Are the prices under investigation the result of an entrenched market power that results from the administrative structure of the State, or due to a privatization process? Are they due to an entrenched market power that results from patents and other, similar rights that stem from industrial property? Are they excessive because the margin of profits is wider than, for example, the average production costs of a given service or product? Besides being exploitative, are these prices exclusionary? These are some of the questions that competitions authority should take into consideration when assessing whether enforcing such provisions.

The decision of enforcing a provision related with excessive and unfair prices also relates to similar policy choices. As mentioned in the previous sections, the possibility that market incumbents engage in abusive behavior, and in some cases, in charging prices like the mentioned above, is much higher in developing countries because of the conditions they exhibit, for example, because of the rather large minimum efficient sales of production relative to their local demand. Also, this may be due to the political and idiosyncratic conditions that have shaped the economic structure of a given country, and that in turn, translate into institutional arrangements that are not for the benefit of the population. In both cases, the role of the State is pervasive. A decision to enforce excessive and unfair price provisions in developing countries has to acknowledge the role of past State-driven policies in the development of these institutional arrangements. Such a decision can be seen as to make amends for past mistakes; it may even be a more responsive State action to cope with principles, goals and purposes that are part of the legal system and that have remained unenforced and unelaborated until now. On the other hand, such decision can be politically disruptive and more damaging than beneficial, especially if it implies affecting local industries that, due to past decisions, have prominence in the present and constitute a valuable source of income for a determined sector of the population. Issues like the relative independence of the competition law authority color this analysis, for their members may be unable to take a decision that is disruptive with decisions taken by other authorities.

It may well be the case that a competition law authority in a developing country may have the relative independence to make this decision. If the particular conditions of their country resembles those commented in the work of authors like Gal, Fox, Brussick and Evenett, it may well decide to investigate and prosecute those firms that charge excessive and unfair prices due to an entrenched market power that has little to do with investment and innovation. This would be mostly consistent with the 
analysis Evans and Padilla offer regarding the difficulties of enforcing article 102.a TFEU in the EU, because the institutional arrangements that underlie this analysis differ from the conditions identified by Brussick and Evenett. As mentioned before, the pervasiveness of the role of the state and the economic structure of markets in developing countries, there is a much higher probability of finding the sort of cases that Evans and Padilla consider to be exceptional in the markets of more developed jurisdictions, and which are suitable for enforcement under the mentioned provision.

At the same time, the analysis suggested by Akman and Garrod, based on the dual entitlement principle, can complement the analysis undergone by these authorities, because it has the virtue of translating abstract notions of fairness in market transactions into competition law policy. Moreover, although the procedure has its own drawbacks ${ }^{107}$, one does wonder to what extent inaction can be more costly, in terms of consumer's welfare, than a proper enforcement of the sort of provisions commented along these lines. Although this particular issue is highly indeterminate, and can only be properly addressed empirically, by itself it does not logically preclude the possibility of improving welfare via competition law enforcement.

There is one final aspect that, so far, has received little attention in the comparative competition law literature, but that deserves further elaboration. This aspect is closely related with the public perception of competition law as a legitimate, public spirited field of policy that can, in many cases, accommodate welfare prescriptions with noneconomic goals related to social mobility and social inclusion. Such is the thrust that drives Eleanor Fox's article, commented above. The idea of "transplanting" a field of law, like competition law, only because of its technical pedigree, may act against its adequate reception, and in particular, may contribute to increase resistance against it. This resistance, whatever color may have, should be taken into consideration if governments take the notion of democratic responsiveness seriously; at the same time, it poses a dilemma, for the resistance may eventually bring forth a competition policy that is ineffective from its inception. Fox argues in favor of striving for a rhetoric of competition law that is compatible to a large extent with the welfarist approach, although it is not based exclusively on it, and that appeals to wider notions of fairness and social inclusiveness. These efforts of grounding competition law in goals and principles that are consistent with economic efficiency, but that do not depend exclusively on it, are highly commendable and can prove a much easier way for cementing a competition law regime's transplant than other available means. In particular, the advantage of implementing the procedure suggested by Akman and Garrod when enforcing excessive and unfair price provisions is that it appeals to notions of fairness that people have, which not only bridges positive and normative discussions about the

107 Pinar Akman \& Luke Garrod, op. cit., p. 3: "Certain adverse effects of a prohibition of excessive pricing will remain even if there is a well defined test. For instance, problems regarding exploitation will only be resolved if remedies restrict the firm's future conduct or change structure of the market". 
role of economics in regulation, but also contribute to the legitimacy of competition policy from a perspective it hasn't been able to benefit from. In turn, these efforts should be developed first and foremost by the competition authorities themselves in their day to day activities and through the decisions they make; failing to do so may imply being unable to receive the popular support that is commonly associated with legitimacy and other democratic values. Perhaps competition law authorities could borrow extensively from the rhetoric of other fields of law that have been successful in complementing technical issues with proper concerns for legitimacy.

\section{BibliograPHY}

\section{Books}

Pinar Akman \& Luke Garrod, When are Excessive Prices Unfair?, CCP Working Paper 10/04 (mar. 2, 2010), available at SSRN http://ssrn.com/abstract=1578181.

Philippe Brusick \& Simon J. Evenett, Should Developing Countries Worry about Abuse of Dominant Power?, 2008 Wis. L. Rev., 269 (2008).

María Coppola Tineo \& Russel Pittman, Abuse of Dominance Enforcement under Latin American Competition Laws, Economic Analysis Group Discussion Paper, available at: www.justice.gov/atr/public/eag/221878.htm.

Competition Law and Policy in Brazil: a Peer Review, available at http://www.oecd.org/ dataoecd/4/42/45154362.pdf.

Chile - Peer Review of Competition Law and Policy, available at http://www.oecd.org/ dataoecd/43/60/34823239.pdf.

Ignacio De León, An Institutional Assessment of Antitrust Policy The Latin American Experience, Kluwer International (2009).

, Latin American Competition Law and Policy: A Policy in Search for Identity, Kluwer Law International (2001).

Hernando De Soto, The Other Path: The Invisible Revolution in the Third World, Harper and Row (1989).

A. De Streel \& M. Motta, Exploitative and Exclusionary Excessive Prices in EU Law, available at: http://professorgeradin.blogs.com/professor_geradins_weblog/files/ ExcessivePrices18122003.pdf.

David S. Evans \& Jorge A. Padilla, Excessive Prices: Using Economics to Define Administrable Legal Rules, Centro de Estudios Monetarios y Financieros (CEMFI), Working Paper 0416 (2004). 
Ariel Ezrachi \& David Gilo, Excessive Pricing, Entry, Assessment, and Investment: Lessons from the Mittal Litigation, 76 Antitrust L. Jnl., 873 (2010). 249 (2009).

, Are Excessive Prices Really Self Correcting?, 5. J. Competition L. and Econ.,

Eleanor M. Fox, Economic Development, Poverty and Antitrust: The Other Path, 13 Sw. J. L. and Trade Am., 211 (2006-2007).

Eleanor M. Fox \& D. Daniel Sokol (eds.), Competition Law and Policy in Latin America, Hart Publishing (2009).

Michal Gal, Reality Bites (or Bits): The Political Economy of Antitrust Enforcement, New York University Law and Economics Working Papers, 57 (2006), available at http:// lsr.nellco.org/nyu_lewp/57.

, Size Does Matter: The Effects of Market Size on Competition Policy, 74 U. of S. Cal. L. Rev., 1437 (2001).

, The 'Cut and Paste' of Article 82 of the EC Treaty in Israel: Conditions for a Successful Transplant, NYU Law and Economics Research Paper, 08-03, available at SSRN http://ssrn.com/abstract=1082035.

David J. Gerber, Law and Competition in Twentieth Century Europe: Protecting Prometheus, Oxford University Press (1998).

Lucas Grosman \& Tomás Serebrisky, El abuso explotativo y la defensa de la competencia en Argentina, 16 Boletín Lat. de la Competencia, 15, pp. 21-22 (2003).

Daniel Kahneman, Jack L. Knetch \& Richard Thaler, Fairness as a Constraint on Profit Seeking: Entitlements in the Market, 76 Am. Econ. Rev., 728 (1986).

William E. Kovacic, Institutional Foundations for Economic Legal Reform in Transition Economies: The Case of Competition Policy and Antitrust Enforcement, 77 Chi.-Kent L. Rev., 265 (2001-2002).

Giorgio Monti, EC Competition Law, Cambridge University Press (2007).

Bruce M. Owen, Competition Policy in Latin America, Stanford Law and Economics Olin Working Paper, 268 (oct. 2003), available at SSRN http://ssrn.com/abstract=456441.

A. E. Rodriguez, Does Legal Tradition Affect Competition Policy Performance?, 21 Intl. Trade Jnal., 417 (2007).

Richard Whish, Competition Law, Oxford University Press (5th ed. 2005). 


\section{LEGAL DOCUMENTS}

\section{República de Argentina}

República de Argentina, Comisión Nacional de Defensa de la Competencia, Acto 22.262 de 1980 .

República de Argentina, Corte Suprema de Justicia de la Nación en autos, Recurso de hecho deducido por Yacimientos Petroliferos Fiscales S.A. en la causa Yacimientos Petroliferos Fiscales S.A. s/ Ley 22.262- Comisión Nacional de Defensa de la Competencia Secretaría de Comercio e Industria, 2 de julio de 2002.

República de Argentina, Secretaría de Industria, Comercio y Minería, Resolución 189 de 22 de marzo de 1999.

\section{South Africa}

Pinar Akman \& Luke Garrod, op. cit., p. 3: "Certain adverse effects of a prohibition of excessive pricing will remain even if there is a well defined test. For instance, problems regarding exploitation will only be resolved if remedies restrict the firm's future conduct or change structure of the market".

South African Competition Appeal Court, Mittal Steel S. Afr. Ltd. v. Harmony Gold Mining Co., (May 29, 2009), available at http:/www.comptrib.co.za/assets/Uploads/CaseDocuments/70CACApr07.pdf.

South African Competition Tribunal, Harmony Gold Mining Co. v. Mittal Steel S. Afr. Ltd. (Mar. 27, 2007), available at http://www.icn-capetown.org.za/comptrib/ comptribdocs/97/13CRFeb04.pdf. 
